\title{
DIAGENETIC TRENDS IN THE PLEISTOCENE CALCAREOUS RIDGES, MERSA MATRUH AREA, EGYPT
}

By

\author{
HANAFY HOLAIL
}

Department of Geology, Faculty of Science

University of Qatar, Doha, Qatar

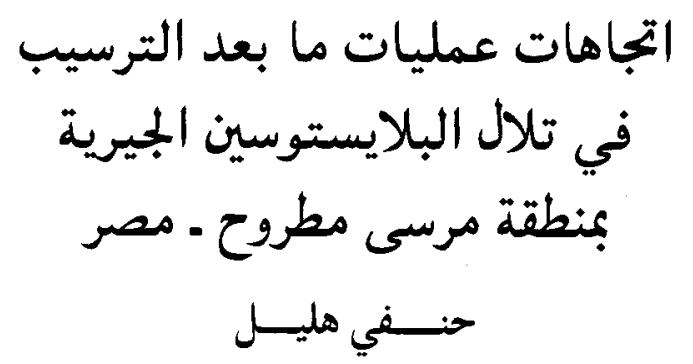

تتواجد صـخو الكربونات التابعة للبلايستوسين عل هيئة تلال بامتـداد السـاحل

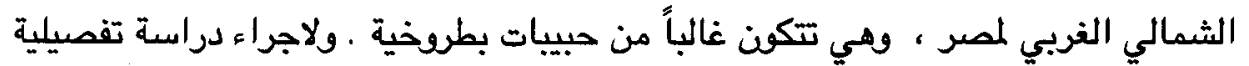

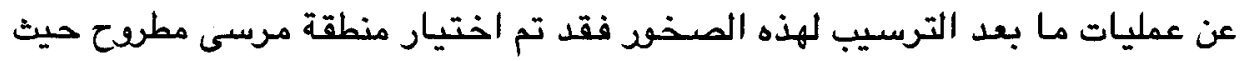

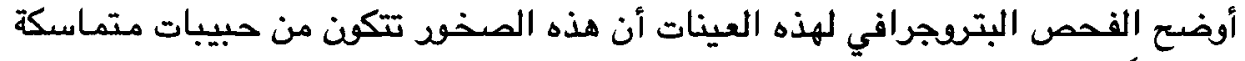

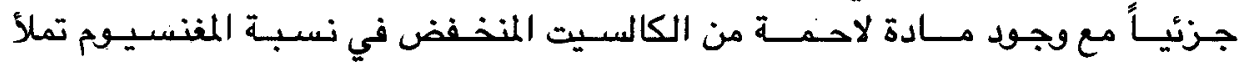
الفراغات البينية .

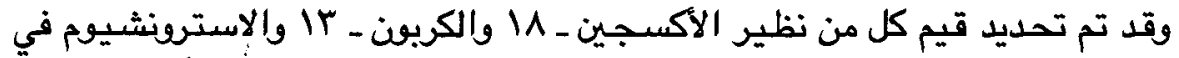

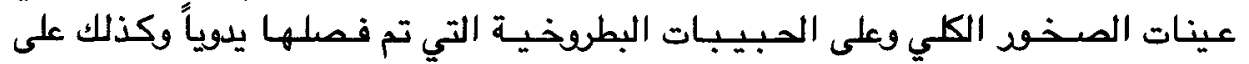

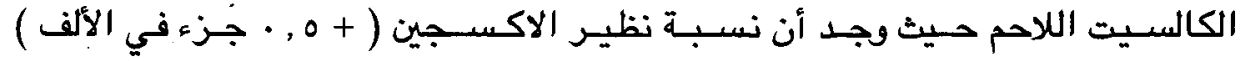

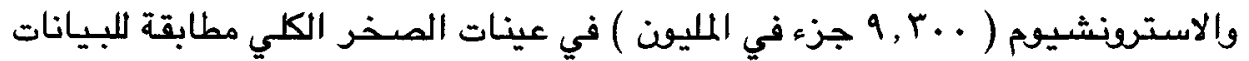

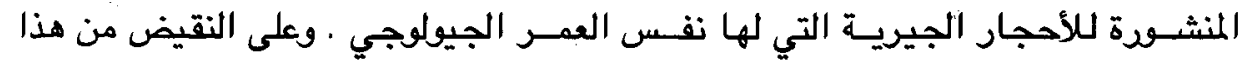

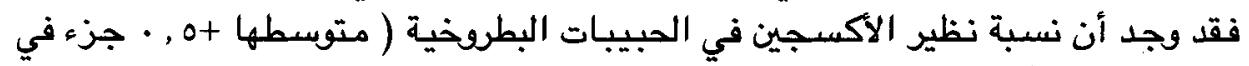

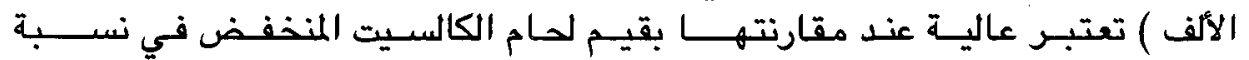

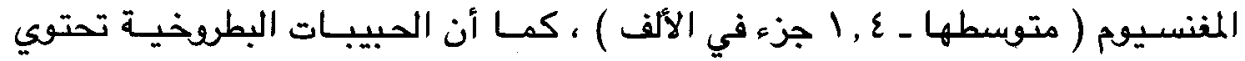

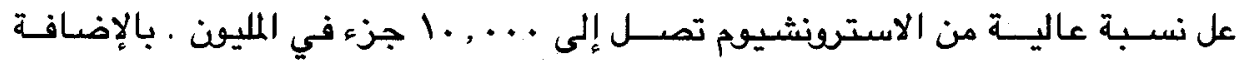

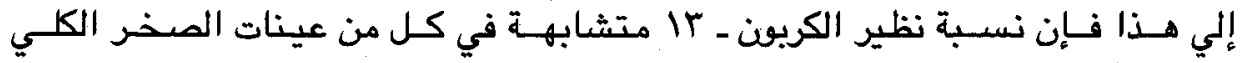

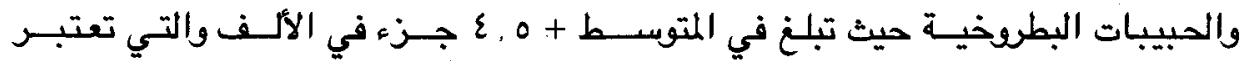

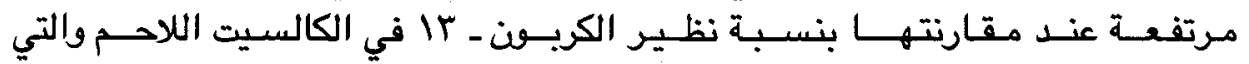

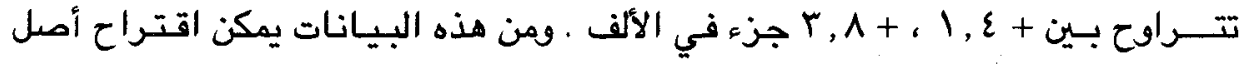

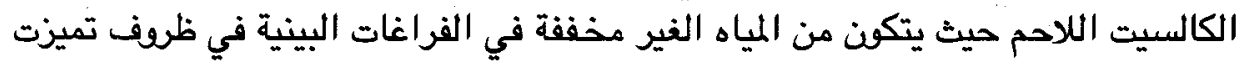

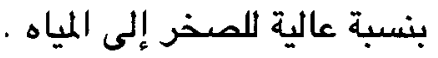

Key Words: Carbonates, Marine, Meteoric, Cementation, Mersa Matruh, Diagenesis, Pleistocene, Calcite, Aragonite, Ooids, Stable isotopes.

\section{ABSTRACT}

Ooids are a major constituent of the Pleistocene carbonates along the northwestern coastal ridges of Egypt. For a detailed diagenetic study of the rocks, the Mersa Matruh area was selected. Petrographic examination shows that the rocks are partly consolidated ooid grainstones with low-Mg calcite cement in granular voids.

$\delta^{18} \mathrm{O}, \delta^{13} \mathrm{C}$, and $\mathrm{Sr}$ values were determined on whole rock samples, on the manually separated ooids and calcite cements. Oxygen 
isotopic and $\mathrm{Sr}$ values for the whole rock (+0.5\%o PDB; $9,300 \mathrm{ppm})$ are consistent with data on limestones of the same age. In contrast, oxygen isotopic values for ooids (average $+0.5 \%$ PDB) are heavier relative to values for low-Mg calcite cement (average $-1.4 \% \mathrm{PDB}$ ) and $\mathrm{Sr}$ contents are higher for ooids $(10.000 \mathrm{ppm})$. In addition, $\delta^{13} \mathrm{C}$ values are identical for the whole rock and ooids (average $+4.5 \% \circ \mathrm{PDB}$ ) and heavier relative to $\delta^{13} \mathrm{C}$ values of the calcite cements (ranging from +4.1 to $+3.8 \% \circ \mathrm{PDB}$ ). These data may suggest that calcite cements are formed in non-diluted pore-water under relatively high rock/water ratios.

\section{INTRODUCTION}

Studies of diagenesis of Quaternary carbonate rocks have yielded an immense amount of information and understanding of meteoric diagenetic processes (Halley and Harris, 1979; Allan and Matthews, 1982; Budd, 1988; Budd and Land, 1990; Saller and Moore, 1991). These studies and others have the obvious advantages of monitoring pore-water chemistry and combining this with detailed petrographic, chemical and mineralogical analyses.

The Pleistocene calcareous ridges along the northwestern coastal zone of Egypt have been extensively investigated in terms of their distribution, sedimentology, origin and diagenesis (Hilmy, 1951; Shukri et al., 1956; Butzer, 1960; El-Shazly et al., 1964; Selim, 1974; Hassoub, 1980; Anwar et al., 1981). However, little attention has been given to the water/rock interaction relationships which potentially control dissolution of carbonate grains (ooids) and precipitation of low-Mg calcite cements.

The present study integrates $\mathrm{Sr}$ and stable isotope data with the petrographic observations of samples collected from two calcareous ridges located in the Mersa Matruh area. These elucidated the fabric, timing, mineralogy, and chemistry of fluids responsible for ooids formation, and the subsequent meteoric diagenesis of the carbonate rocks.

\section{GEOLOGICAL SETTING}

The Mersa Matruh area, locate in the northwestern coastal zone of Egypt (Fig. 1), has a uniform topographic relief with Pleistocene calcareous ridges parallel to the coast and separated by flat-bottomed depressions. Ridges sediments are composed predominantly of well-sorted, medium-grained aragonitic ooids sands. Their internal geometry and sedimentary structures are characteristics of wind-formed-dune deposits. Several meters of horizontal stratification adjoining cross-stratification inclined up to $32^{\circ}$ and convex towards the top are present.

In the study area, there are three calcareous ridges of late Monasterian to Tyrrhenian age (Zeuner, 1952, Shukri et al., 1956). Samples were collected from the first (coastal, younger ridge) and second (inland, older ridges). Sediments in both ridges show that most of the diagenetic alteration (cementation) can be related to meteoric diagenesis. However, ooids sands of the coastal ridges are weakly-cemented relative to those of the inland ridge. The present Mediterranean sea level has been relatively stable for the past 2,000 to 3,000 yrs, as compared to a fast-rising sea level 3,000 to 15,000 yrs ago (Butzer and Cuerda, 1962). These changes in sea level have had an effect on the position of the meteoric-marine zone since the deposition of the Pleistocene calcareous ridges.

The present hydrologic regime of the study area consists of thin freshwater lenses underlines by a brackish transitional zone which varies in salinity and extent in response to freshwater recharge. The freshwater lenses are transient due to seasonal variations in rainfall. The thickness, volume, and areal extent of these lenses are greatest immediately after the rainy season which ends by March (average annual rainfall of $180 \mathrm{~mm}$, mean annual temperature $33^{\circ} \mathrm{C}$ to $15^{\circ} \mathrm{C}$ ). Meanwhile, the minor tidal effects and the absence of groundwater discharge result in a thin mixing zone at the Mersa Matruh area.

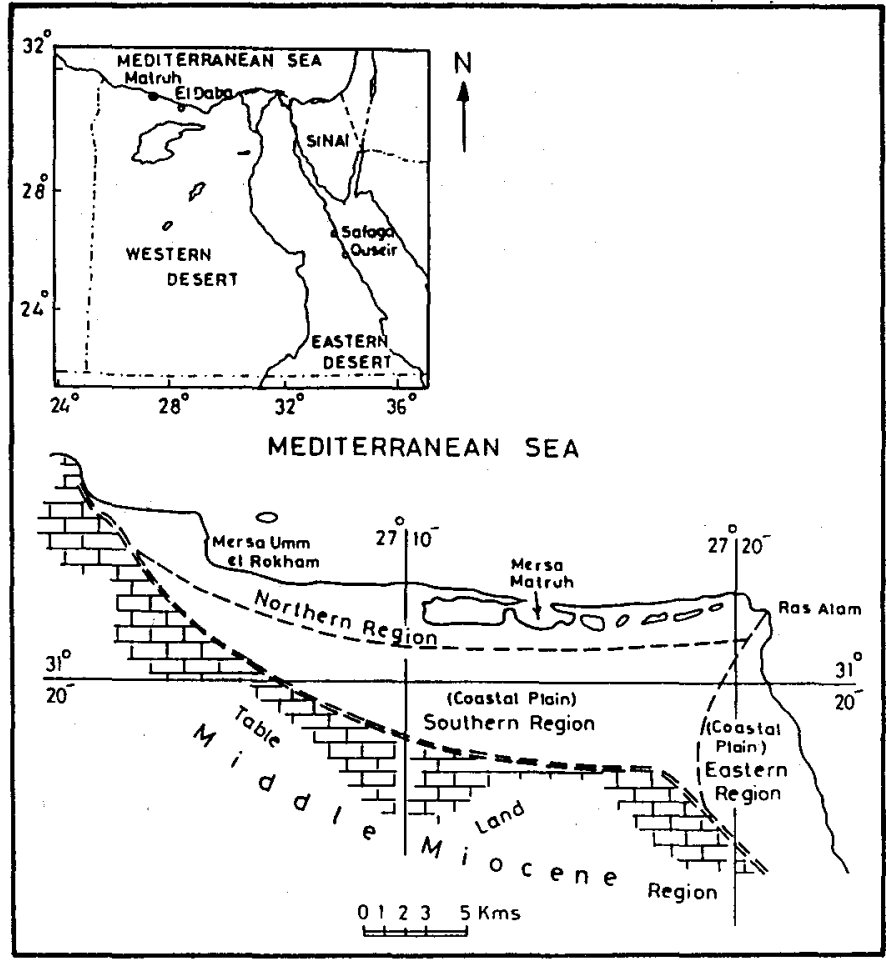

Fig. 1: Generalized geologic map of Mersa Matruh area, Egypt.

\section{MATERIAL AND METHODS}

In order to investigate the possible interaction of meteoric water with the oolitic calcareous rocks, a sampling scheme was chosen which traverses ridges and extends laterally from coastline towards table land (old ridge). Forty representative samples from both ridges were collected for microfabric, petrographic and geochemical analyses.

Polished thin-sections were prepared and examined by standard optical microscopy and cathodoluminescent petrography. Chips and polished thin-sections (etched by $50 \%$ glacial acetic acid) of selected samples were coated with a thin layer of gold and examined with the scanning electron microscope. Sample powder was X-rayed to ensure mineral purity prior to chemical and isotopic analyses. Strontium contents for the same powders were determined by atomic absorption spectrophotometry.

Texturally distinct ooids and cements, as well as whole rocks, were sampled for oxygen and carbon isotope analysis. Ooids and cements of twenty samples (ten from each ridge) were manually separated under a binocular microscope. Powdered samples were then roasted under vacuum for $1 \mathrm{~h}$ at $380^{\circ} \mathrm{C}$ for the cements and at $100^{\circ} \mathrm{C}$ for the whole rock and ooids. The difference in roasting temperature is to eliminate any possibility of conversion of aragonite to calcite. After 
roasting, samples were treated with anhydrous phosphoric acid at $50^{\circ} \mathrm{C}$ in an in-line extraction system connected to the inlet of a VG 602 E Micromass ratio mass spectrometer. Isotope enrichments are corrected for ${ }^{17} \mathrm{O}$ contributions and are reported relative to the PDB carbonate standard (Craig, 1957). Precision of analysis was $0.09 \%$ for oxygen and $0.07 \%$ for carbon based on daily analysis of NBS-20 analyzed as an unknown carbonate powder.

\section{RESULTS AND DISCUSSION}

\section{Carbonate mineralogy}

In the whole rock samples, aragonite and low-Mg calcite are the only carbonate minerals detected in measurable amounts (Fig. 2). The aragonite contents of the coastal ridge range from $99 \%$ to $94 \%$, with the lowest values in the inland ridge (Fig. 3). Moreover, all ooids are composed of aragonite, and the cement consists of low-Mg calcite.

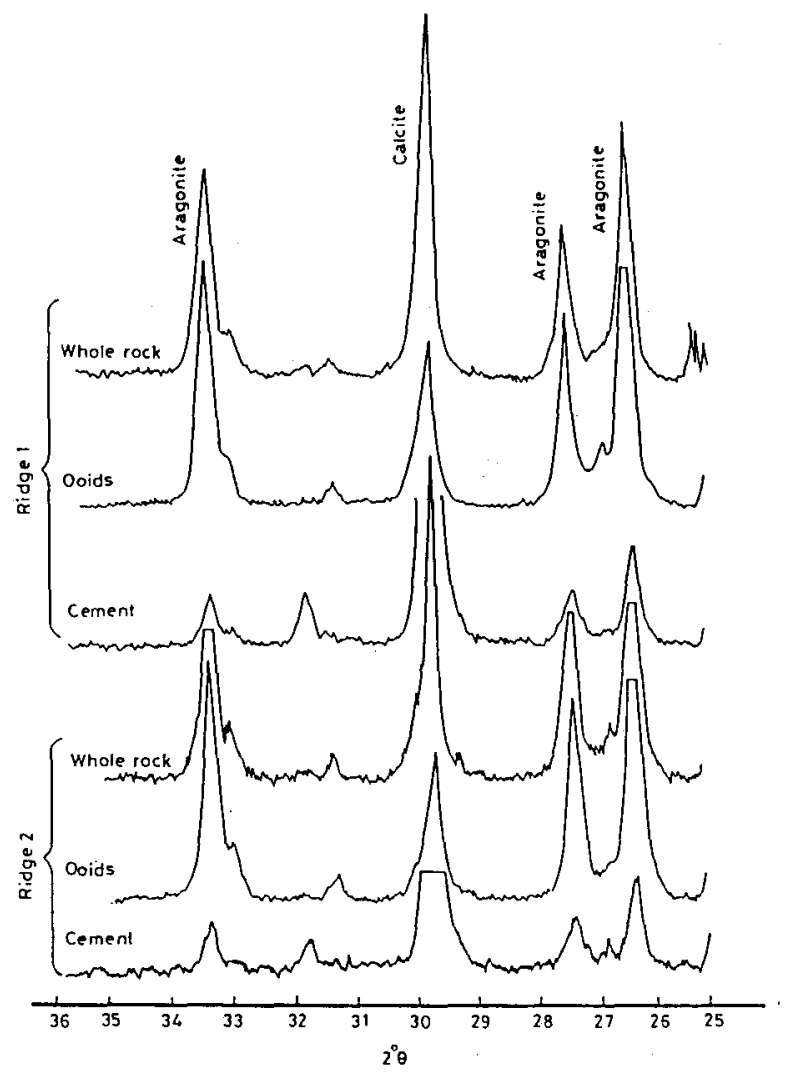

Fig. 2: X-ray diffractograms showing minerals of whole rocks, ooids and cements for samples from the coastal (1) and the inland ridges (2).

Compositionally, modern ooids may consist of low-Mg calcite, high- $\mathrm{Mg}$ calcite, and aragonite with more than one phase commonly occurring within an individual cortex (Land et al., 1979; Medwedeff and Wilkinson, 1983). However normal marine ooids are composed of aragonite (Newell et al., 1960; Purdy, 1963; Friedman et al., 1973); calcite ooids are much less abundant in modern environments (Popp and Wilkinson, 1983). Mechanisms invoked to explain the mineralogy of ooids are highly dependent on $\mathrm{Mg} / \mathrm{Ca}$ ratio, hydrodynamic parameters (Given and Wilkinson, 1985), and the tectonically induced changes in $\mathrm{PCO} 2$ (Mackanzie And Pigott, 1981). The $\mathrm{Mg} / \mathrm{Ca}$ ratios of seawater during Pleistocene time were favoring formation of aragonitic ooids (Given and Wilkinson, 1985).

\section{Petrography}

In the Mersa Matruh area, an important lithic feature is the variable preservation of primary ooids fabric from the coastal to the inland ridges. In the coastal ridge, well developed ooids are easily identified; whereas, samples from the adjacent inland ridge exhibit a partial loss of the primary ooids fabric. More striking is the variation of calcite cement (Fig. 4). The amount of calcite cement, as determined by X-ray diffraction, ranges from $15 \%$ to $26 \%$ in the inland ridge; whereas, the coastal ridge contains $\sim 5 \%$ (Fig. 3 ).

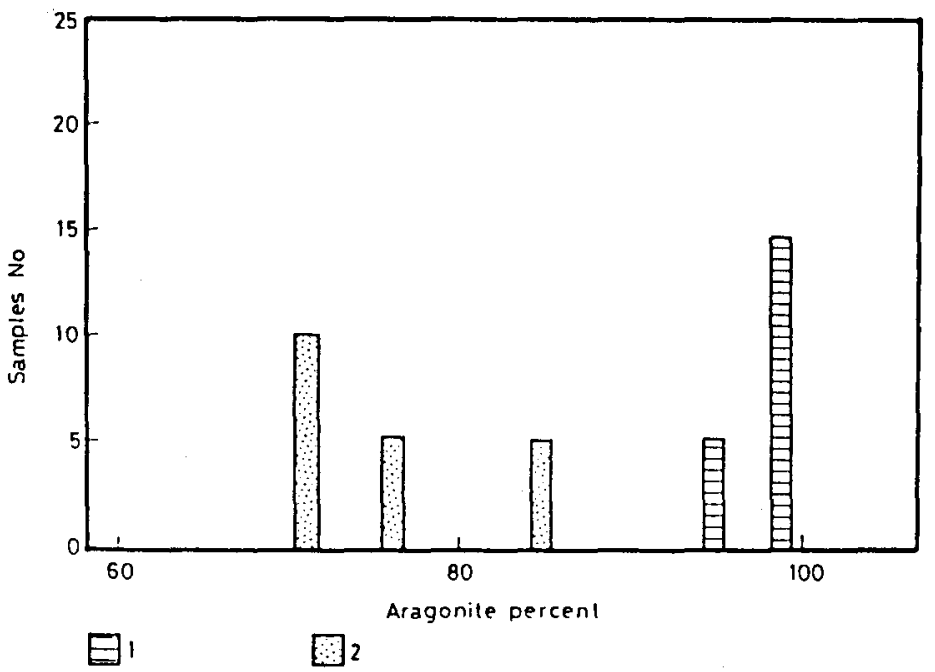

Fig. 3: Bar diagrams showing relative proportions of aragonite in samples from the coastal (1) and the inland ridges (2).

Ooids grains of the coastal ridge are weakly-cemented relative to those of the inland ridge. In general, ooids in both ridges are well-sorted and medium-grained, with rare fossil debris. Ooids display concentric fabrics, with no radial orientation (Figs. 4 and 5). The ooids nuclei are, in most cases, limestone fragments (Figs. 4 and $5 F$ ) which are not easily discernible in every case. In others, the nuclei are made of shell debris or terrigenous quartz. Ooids have a relatively thick cortex which exhibits more than 40 laminae. The individual lamina exhibits characteristic fabrics. Aragonite crystallites always occur as short, fibrous laths to needles (Fig. 5E). The lack of bimineralic compositions in the ooid cortices may reflect a lack of fluctuating water chemistry during their formation.

Ooid grains are cemented by low-Mg calcite in which the individual crystals are oriented perpendicular to the surface of ooids (Fig. 5C-D), thus the pore spaces are partially occluded. In the coastal ridge, ooid grains are generally poorly cemented. Cements are commonly in grain contact positions, bridging grains and forming meniscus cement (Fig. 4A) .In contrast, the cement in the inland ridge is more evenly distributed as isopachous crusts around the ooid grains (Fig. 4B).

The concentric fabrics of the Pleistocene calcareous ooids are considered primary. There is no evidence for any major diagenetic alteration of the ooids other than the partial dissolution of some of them. Ooids have been partially micritized by algal boring (Fig. 5F). Meanwhile, ooids are not cathodoluminescent. This is consistent with the primary origin for aragonite, since aragonite which was precipitated directly from seawater contains insufficient manganese to be cathodoluminescent, because the concentration. of divalent manganese in seawater was probably too low. 

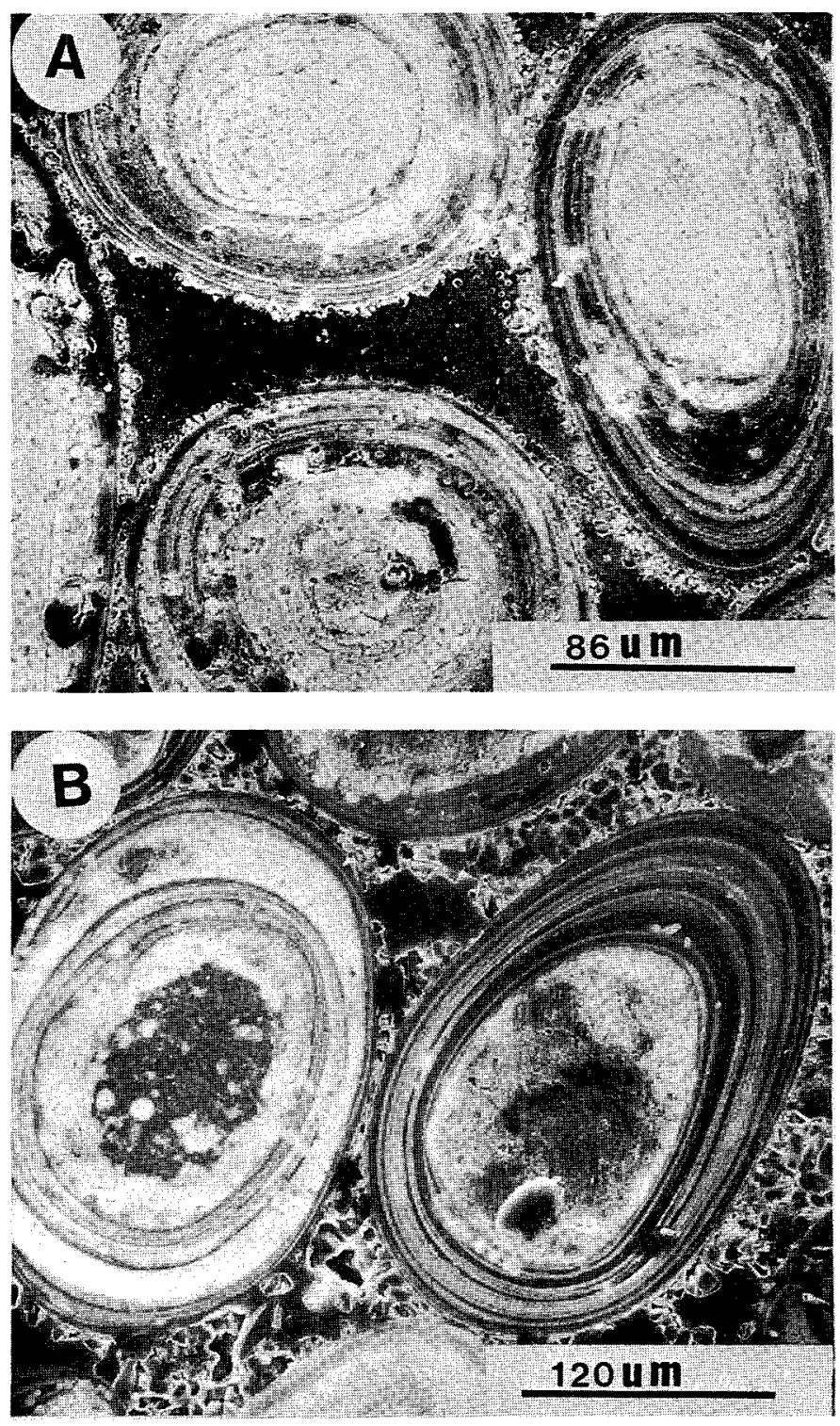

Fig. 4: SEM photomicrographs of the Pleistocene carbonate rocks. Samples were sectioned, polished, and etched by $50 \%$ glacial acetic acid. A-Coastal ridge. B- Inland Ridge. The amount of cement in the inland ridge is more than that in the coastal ridge.

\section{Geochemistry}

\section{Strontium}

Strontium contents of the Pleistocene calcareous ridges are positively correlated with the aragonite content (Fig.6). The concentration of $\mathrm{Sr}$ in calcite cements can be related to the composition of the precipitating solution through the partition coefficient (D)

$$
(\mathrm{Sr} / \mathrm{Ca})_{\text {calcite }}=\mathrm{D}_{\mathrm{Sr}}(\mathrm{Sr} / \mathrm{Ca})_{\text {fluid }}
$$

The partition coefficients for $\mathrm{Sr}$ in calcite vary according to temperature, ion concentrations, and rate of precipitation (Lorens, 1981; Pingitore and Eastman, 1986 ; Morse and
Bender, 1990). Calculated partition coefficients for $\mathrm{Sr}$ in calcite range from 0.03 (Lorens, 1981) to 0.14 (Kinsman, 1969); whereas, a partition coefficient of 0.055 is probably a reasonable estimate for precipitation of $\mathrm{Sr}$ into low-Mg calcite cement in natural near-surface system (Budd and Land 1990).

In the present study, the high $\mathrm{Sr}$ contents of the aragonitic ooids $(9,200$ to $10,000 \mathrm{ppm}$; Table 1$)$ are consistent with the $\mathrm{Sr}$ contents of modern aragonitic ooids from Bahama and Baffin Bay (Halley and Harris, 1979, Land et al., 1979). These high $\mathrm{Sr}$ values are in accord with the theoretical prediction for marine aragonitic ooids, and indicate their direct precipitation from ambient seawater.

The low-Mg calcite has significantly higher $\mathrm{Sr}$ contents (4,000 to $6,000 \mathrm{ppm})$ than those of most meteoric calcite cements. In view of the value of $\mathrm{D}^{\mathrm{Sr}}$ calcite, it is unlikely that the low-Mg calcite cement retained $\sim 50 \%$ of $\mathrm{Sr}$ contents in the aragonitic ooids. The observed $\mathrm{Sr}$ concentrations are high enough even to be comparable to the equilibrium value for marine water calcite . Utilizing the partition coefficient of Kinsman (1969), calcite in equilibrium with seawater should contain about $1100 \mathrm{ppm} \mathrm{Sr}$. The concentration of $\mathrm{Sr}$ in meteoric calcite depends mostly on the Sr partition coefficient and its concentration in the meteoric water. Meteoric water which is commonly considered in the transformation of metastable $\mathrm{CaCO}_{3}$ (aragonite and/or high- $\mathrm{Mg}$ calcite) to low -Mg calcite, is generally low in $\mathrm{Sr}$ content. Due to this fact and that the Sr partition coefficient is $<1$, the meteoric calcite should show low concentrations of Sr. Budd and Land (1990) and Saller and Moore (1991) found very high $\mathrm{Sr}$ concentrations (600 to $3,700 \mathrm{ppm}$ ) in meteoric calcite cements precipitated in the Holocene and Pleistocene aragonitic ooids. Given the fact that aragonite dissolution is the dominant source of aqueous $\mathrm{Sr}$, a large quantity of aragonitic ooids must have been dissolved into the aqueous system to account for the enhanced concentration of $\mathrm{Sr}$ in the low-Mg calcite cements of the Pleistocene calcareous ridges.

\section{Stable oxygen and carbon isotopes}

In order to infer cementation conditions in the Pleistocene calcareous ridges, the oxygen and carbon isotopic composition of the whole rocks, ooids (aragonite), and cements (low-Mg calcite) have been determined (Fig 7). These isotopic data can be explained by the general model for early near surface meteoric diagenesis (Land 1970); Wagner , 1983; James and Choquette 1984).

Results of oxygen and carbon stable isotope analyses are summarized in Table 1. Stable oxygen isotope ratios are generally enriched in the whole rocks $(+0.6$ to $+0.5 \%$ PDB $)$ and the ooids ( +0.6 to $+0.3 \%$ PDB) and depleted in the calcite cements. The Coastal ridge calcite cements $\delta^{18} \mathrm{O}$ values (average $-1.0 \%$ PDB) are more enriched than those of the inland ridge (average-1.7\% $\mathrm{PDB}$ ) .So the transition from the coastal ridge into the inland ridge is marked by a pronounced 0.7 per mil shift in $\delta^{18} \mathrm{O}$ of the calcite cement towards the more depleted. The $\delta^{13} \mathrm{C}$ values of the whole rocks and ooids are identical for both ridges (average $+4.5 \%$ PDB) and are close to their calcite cement values ( +4.1 to $+3.8 \%$ PDB).

The $\delta^{18} \mathrm{O}$ values of carbonate rocks are sensitive indicators of alteration (Brand and Veizer 1981). The studied ooids show a limited range of $\delta^{18} \mathrm{O}$ values from +0.6 to $+0.3 \%$ PDB. The values are similar to modern ooids and suggest that the present isotopic compositions can reflect equilibrium with marine water. In contrast, the calcite cements have noticeably lower $\delta^{18} \mathrm{O}$ values $(-1.0$ to $-1.7 \%$ PDB. Table 1$)$. These low $\delta^{18} \mathrm{O}$ 

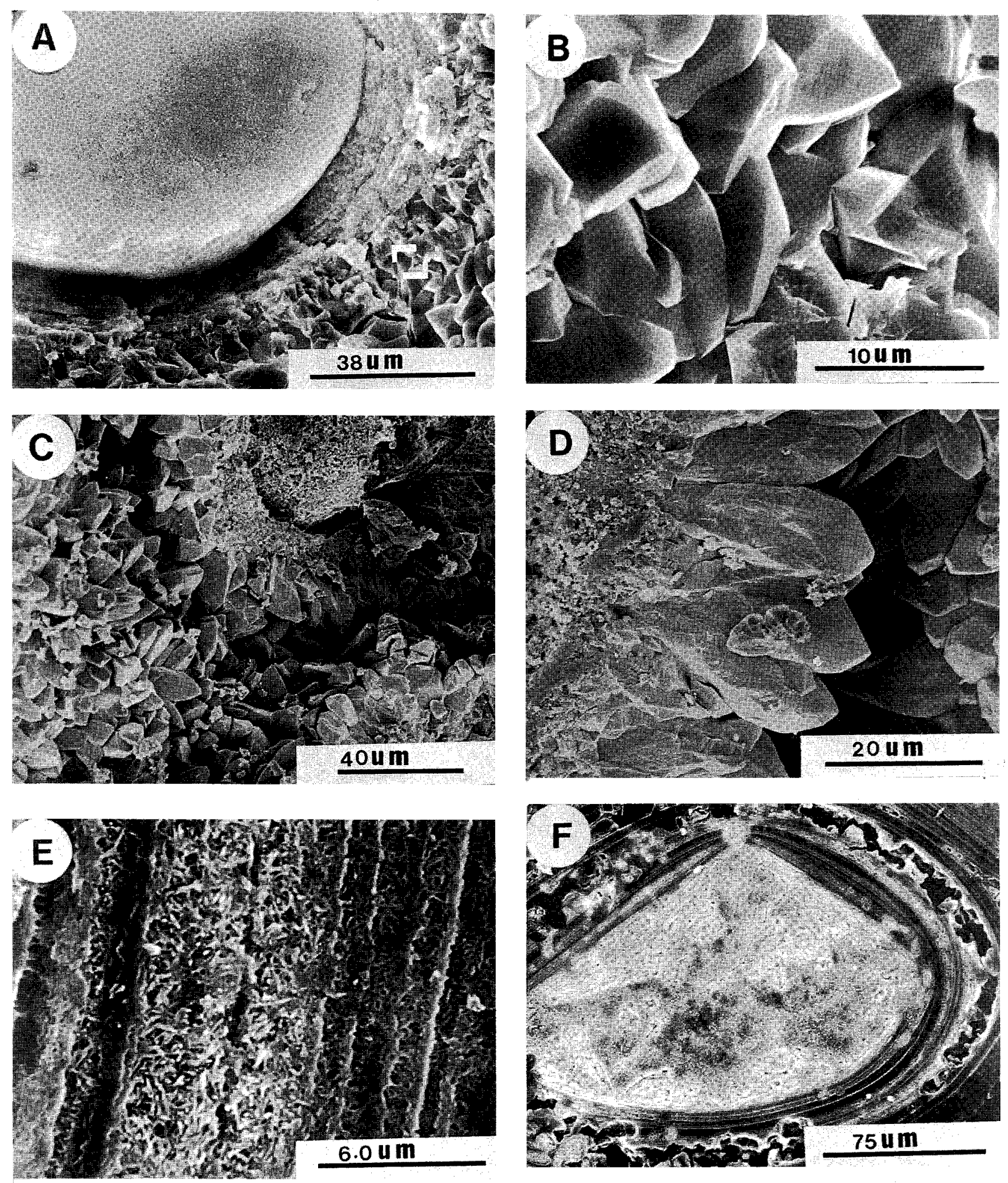

Fig. 5: SEM photomicrographs of cementation and dissolution features. A - Well rounded ooid with visible nuclei, concentric laminae and calcite cement. B - Enlargement of low-Mg-calcite cement crystals. C - Partly dissolved ooid-nuclei, the interparticle pores are partially filled with calcite cement spar. D - calcite cement crystals are oriented perpendicular to the ooid surface. E - SEM photomicrograph of strongly etched ooid showing individual aragonite lamina. F - Microboring dissolution in ooid cortex. 
values are most likely the result of alteration by meteoric water. In north Jamaica, diagenetic calcite formed in the Pleistocene marine sediments are in isotopic equilibrium with unevaporated meteoric water with $\delta^{18} \mathrm{O}$ values between -3.2 and $-2.3 \%$ (Land and Epstein, 1970). In the study area, evaporation is significant, therefore slightly evaporated meteoric water, enriched in $\delta^{18} \mathrm{O}$ could precipitate calcite cements different from the meteoric calcite. This indicates that precipitation of low- $\mathrm{Mg}$ calcite cements was induced by evolution of $\mathrm{CO}_{2}$ from the dissolution of aragonitic ooids. This evolution was, in turn, influenced by the degree of evaporation which occurred in the near-surface environment.

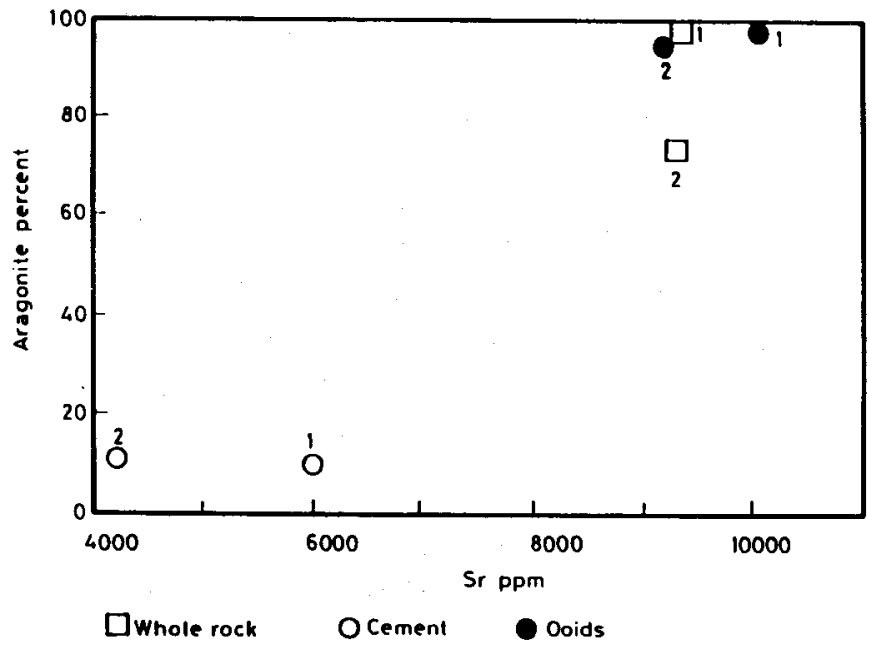

Fig. 6: Relation between average $\mathrm{Sr}$ content and average aragonite content in the coastal (1) and the inland ridges (2).

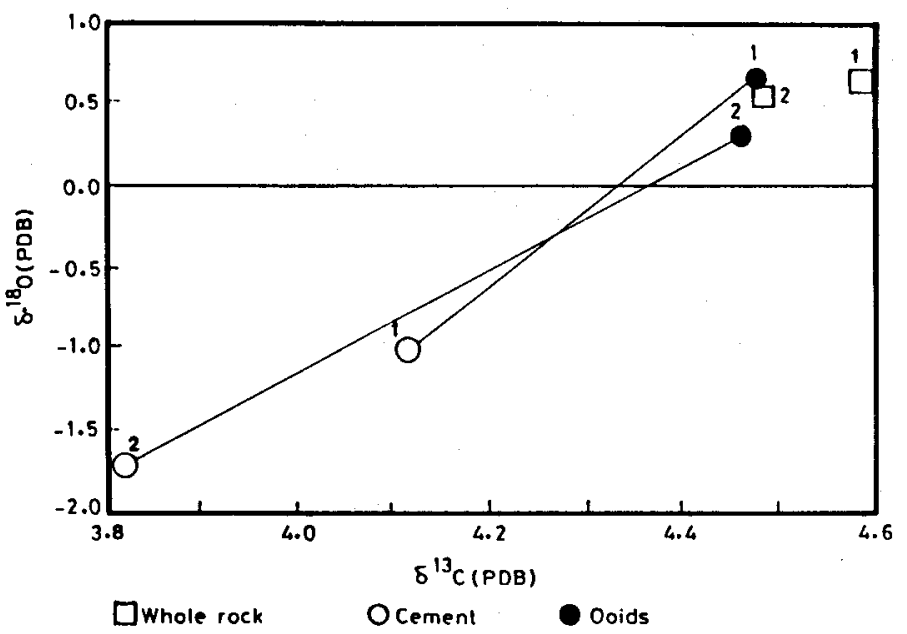

Fig. 7: Average isotopic compositions of the coastal (1) and the inland ridges (2).

The $\delta^{18} \mathrm{O}$ values of the whole rock for both ridges are identical (Table 1) and display no systematic variations within each ridge. This indicates that the conventional whole rock analysis can not be applied successfully to provide such variations and trends of alteration by meteoric water.
Table 1

Average aragonitic content, oxygen and carbon isotopic compositions, and Sr elemental data of samples from the Pleistocene calcareous ridges.

\begin{tabular}{|c|c|c|c|c|c|c|}
\hline & & $\mathbf{n}$ & $\begin{array}{l}\text { Aragonite } \\
\%\end{array}$ & $\begin{array}{c}\delta^{18} \mathrm{O} \\
(\mathrm{PDB})\end{array}$ & $\begin{array}{c}\delta^{13} \mathrm{C} \\
(\mathrm{PDB})\end{array}$ & $\begin{array}{l}\text { Sr } \\
\text { (PPM) }\end{array}$ \\
\hline $\begin{array}{l}\text { Coastal } \\
\text { Ridge } \\
\text { (1) }\end{array}$ & $\begin{array}{c}\text { Whole Rock } \\
\text { Ooids } \\
\text { Cements }\end{array}$ & $\begin{array}{l}20 \\
10 \\
10\end{array}$ & $\begin{array}{l}97 \\
98 \\
10\end{array}$ & $\begin{array}{l}+0.6 \\
+0.6 \\
-1.0\end{array}$ & $\begin{array}{l}+4.6 \\
+4.5 \\
+4.1\end{array}$ & $\begin{array}{r}9320 \\
10010 \\
5970\end{array}$ \\
\hline $\begin{array}{c}\text { Inland } \\
\text { Ridge } \\
(2)\end{array}$ & $\begin{array}{c}\text { Whole Rock } \\
\text { Ooids } \\
\text { Cements }\end{array}$ & $\begin{array}{l}20 \\
10 \\
10\end{array}$ & $\begin{array}{l}74 \\
95 \\
11\end{array}$ & $\begin{array}{l}+0.5 \\
+0.3 \\
-1.7\end{array}$ & $\begin{array}{l}+4.6 \\
+4.5 \\
+3.8\end{array}$ & $\begin{array}{l}9290 \\
9210 \\
4190\end{array}$ \\
\hline
\end{tabular}

It is significant that a straight mixing line can be constructed between the $\delta^{18} \mathrm{O}$ values of aragonitic ooids (marine end member) and those of low-Mg calcite cements (meteoric end member). The whole rock $\delta^{18} \mathrm{O}$ values of the studied carbonates would be the weighted average of the $\delta^{18} \mathrm{O}$ values of the primary marine ooids and $\delta^{18} \mathrm{O}$ values of the calcite cements. Therefore, the $\delta^{18} \mathrm{O}$ values of the whole rock should fall on the mixing line between the values of the two end members (Figs. 8, 9 and 10). However, the $\delta^{18} \mathrm{O}$ values were shifted away from the mixing line. This might indicate the presence of more than two end members, a fact which is not clearly confirmed by the petrographic examination of the rocks.

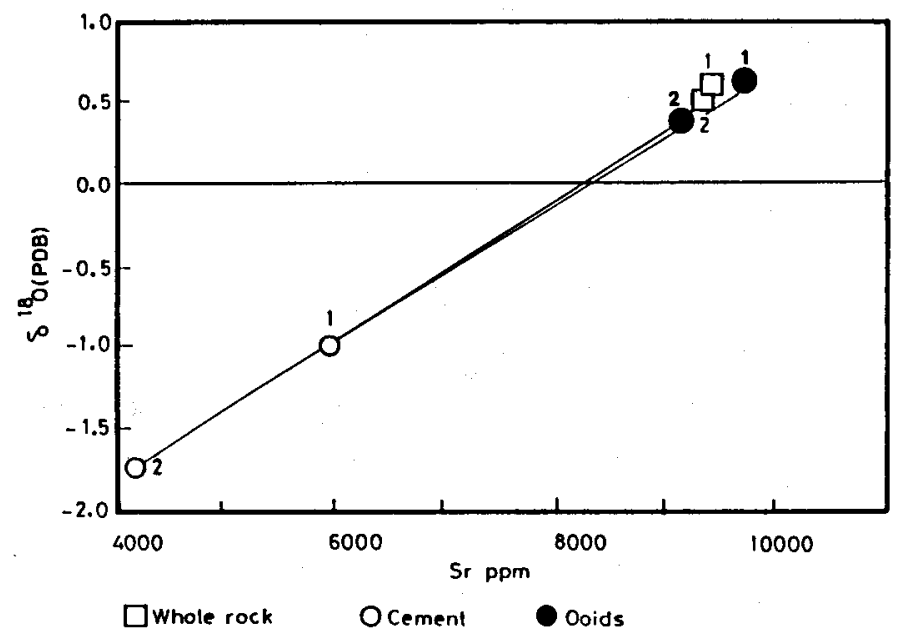

Fig. 8: Relation between average Sr content and average $\delta^{18} \mathrm{O}$ values of the coastal (1) and the inland ridges (2).

The $\delta^{18} \mathrm{O}$ values of marine aragonitic ooids $(+0.3 \%$ o $\mathrm{PDB})$ were used to calculate ambient water temperature using Grossman and Ku's equation (1986), assuming present-day seawater values of $\mathrm{O}(\mathrm{SMOW})$ :

$$
\mathrm{T}\left({ }^{\circ} \mathrm{C}\right)=20.6-4.34\left(\delta^{18} \mathrm{O}_{\mathrm{A}}-\delta \mathrm{W}\right)
$$

where $\delta^{18} \mathrm{O}_{\mathrm{A}}$ is the measured oxygen isotopic ratio of the aragonitic ooids relatives to $\mathrm{PDB}$; and $\delta \mathrm{w}$ is the oxygen isotope ratio of the ambient seawater relative to SMOW. This calculation gives an ambient temperature of $\sim 20^{\circ} \mathrm{C}$ at the time of ooid formation. 


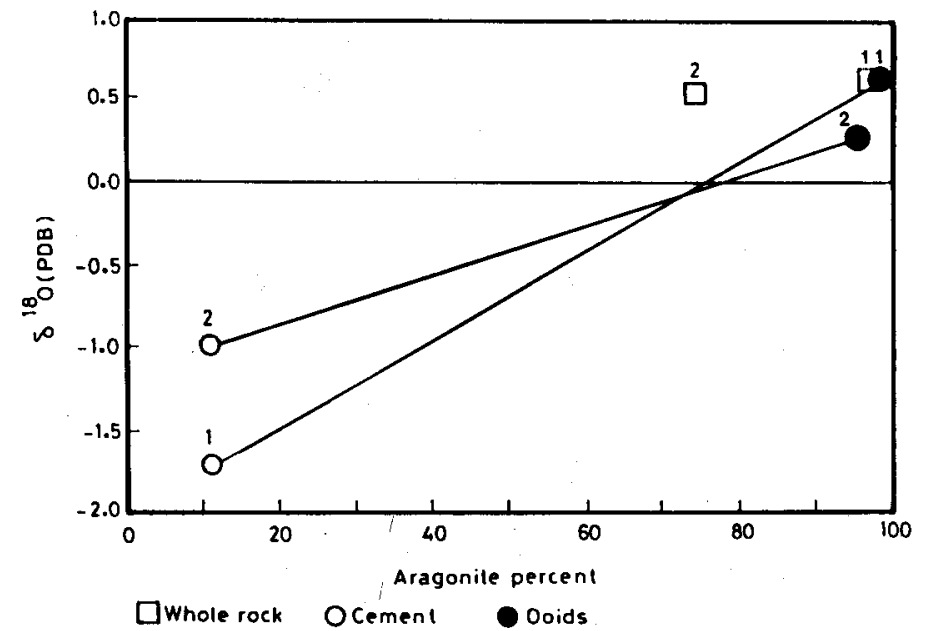

Fig. 9: Relation between average aragonite content and average $\delta^{18} \mathrm{O}$ values of the coastal (1) and the inland ridges (2).

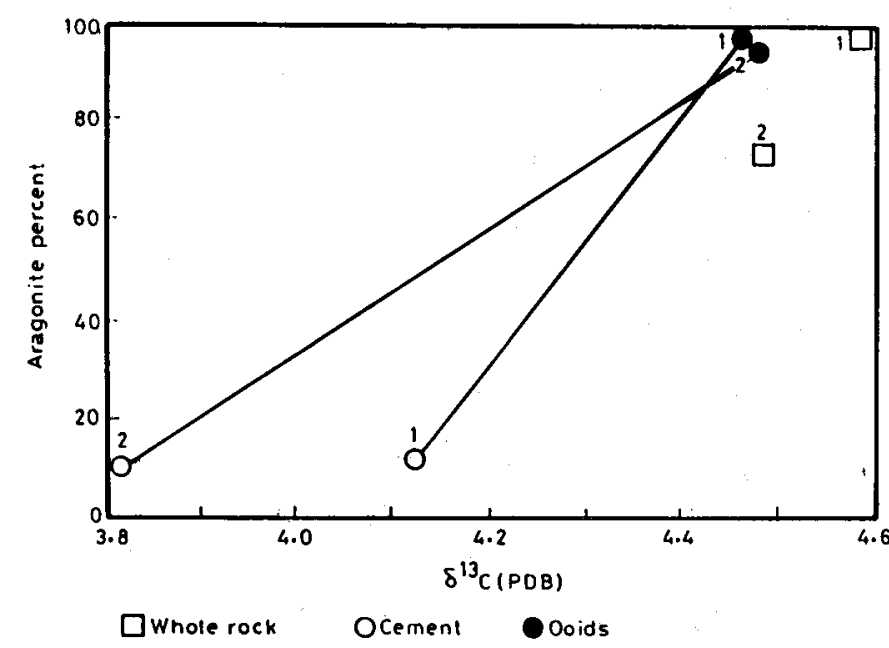

Fig. 10: Relation between average aragonite content and average $\delta^{13} \mathrm{C}$ values of the coastal (1) and the inland ridges (2)

Finally, the aragonitic ooids and the whole rocks, preserve the highest $\delta^{13} \mathrm{C}$ values with an average of $+4.5 \%$ PDB. These carbon isotopic compositions are characteristic of the bicarbonate of inorganic origin derived from seawater or primary marine carbonate dissolution (Budd and Land, 1990). The $\delta^{13} \mathrm{C}$ values of the calcite cements $(+4.1$ to $+3.8 \%$ PDB $)$ are close to values of the ooids. These values suggest that the calcite cements are not in isotopic equilibrium with meteoric water. Therefore, the ${ }^{13} \mathrm{C}$-enriched carbon should have been derived from the dissolved aragonite and did not equilibrate with carbon from other sources (e.g. Budd, 1988; Lohmann, 1988). However, the slight depletion of the $\delta^{13} \mathrm{C}$ values of the calcite cements relative to those values of the ooids might indicate that source from dissolved atmospheric and organic $\mathrm{CO}_{2}$ had a little influence on the carbon isotopic composition of the fluids that precipitated calcite cements. So, the enriched $\delta^{13} \mathrm{C}$ values of the calcite cements reflects a dominance of carbon from dissolved aragonite.

\section{CONCLUSIONS}

The petrographic observations together with $\mathrm{Sr}$ and stable isotope data of rocks from the Pleistocene calcareous ridges present evidences for an early near-surface meteoric diagenesis. The diagenetic features within these rocks shows indications of early aragonitic ooids dissolution and a distinctive phase of low-Mg calcite cementation. There is no evidence of recrystallization by crystal boundary migration or replacement during the transformation process.

The stable isotopic data and Sr contents may suggest that the calcite cements were formed in non-diluted pore-water and at relatively high rock-water ratios. The aragonite ooids dissolution must account for the high $\mathrm{Sr}$ concentration and enrichment of ${ }^{18} \mathrm{O}$ and ${ }^{13} \mathrm{C}$ of pore-water which formed the calcite cements. Meanwhile, the oxygen reservoir might have been influenced by evaporation (enriched ${ }^{18} \mathrm{O}$ ) which occurred in the near surface environment.

The $\delta^{13} \mathrm{C}$ values of the aragonite ooids (+4.5\% $\left.\mathrm{PDB}\right)$ are similar to those of low-Mg calcite cements $(+4.1$ to $3.8 \%$ PDB). This suggests a localized transformation in a system that was closed with respect to carbon with no introduction of carbon from a non-aragonite source. Carbon from organic respiration still would affect the carbon isotopic signature.

\section{ACKNOWLEDGEMENTS}

I would like to thank Prof. A. Selim, Prof. El-Bouseily, Prof. B. Wilkinson and Prof. K. Lohmann for their encouragement and advice throughout the course of this work.

Trace elements and stable isotopic analyses were carried out at the University of Michigan (U.S.A.) Stable Isotope Laboratory.

\section{REFERENCES}

Allan, J.R. and R.K. Matthews, 1982. Isotope signature associated with early meteoric diagenesis. Sedimentology, 29: 797-818.

Anwar, Y.M., M.A. El-Askary, and S.M. Nasr, 1981. Petrography and origin of the oolitic carbonate sediments of Arab's Bay, western part of the continental shelf of Egypt. N. JB. Geol. Palaont. Mh., 2: 65-75.

Brand, U. and J. Veizer, 1981. Chemical diagenesis of multicomponent carbonate system-2: Stable isotopes. Jour Sed. Petrology, 51: 987-998.

Budd, D.A. and L.S. Land, 1990. Geochemical imprint of meteoric diagenesis in Holocene ooids sands Schooner Cays, Bahamas: Correlation of calcite cement geochemistry with extant groundwaters. Jour. Sed. Petrology, 60: 361-378.

Budd, D.A., 1988. Aragonite to calcite transformation during freshwater diagenesis of carbonates: insights from porewater chemistry. Geol. Society Am. Bull., 100: $1260-1270$.

Butzer, K.W., 1960. On the Pleistocene shore lines of Arabs Gulf, Egypt. Jour. Geology, 68: 626-637.

Butzer, K.W., and J. Cuerda, 1962. Coastal stratigraphy of southern Mallorca and its implications for the Pleistocene chronology of the Mediterranean Sea. Jour. Geology, 70: 398-416. 
Craig, H., 1957. Isotopic standard for carbon and oxygen and correction factors for mass spectrometric analysis of carbon dioxide. Geochim. Cosmochim. Acta, 12: 133-149.

El-Shazly, M.M., A.A. Shata and I.M. Farag, 1964. Lithology of the Neogene and Post-Neogene sediments in Mersa Matruh area. Jour. Geology, UAR. Cairo, 8: 21-45.

Freidman, G.M., A.J. Amiel, M. Braun, and D.S. Miller, 1973. Generation of carbonate particles and laminates in algal mats. Examples from a sea marginal hypersaline pool, Gulf of Aqaba, Red Sea. Am. Assoc. Petrol. Geol. Bull., 57: 551-557.

Given, R.K., and B. Wilkinson, 1985. Kinetic control of morphology, composition, and mineralogy of abiotic sedimentary carbonates. Jour. Sed. Petrology, 55: 109-119.

Grossma, E.L. and T.L. Ku, 1986. Oxygen and carbon isotope fractionation in biogenic aragonite: Temperature effects. Chem. Geol., 59: 58-74.

Halley, R.B., and P.M. Harris, 1979. Freshwater cementation of a 1,000 year-old oolite. Jour. Sed. Petrology, 49: 969-988.

Hassouba, A.H., 1980. Quaternary sediments from the Coastal plain of northwetern Egypt (from Alexandria to El-Omayid), (Unpub. Ph.D. Thesis), England, Imperical College, $320 \mathrm{pp}$.

Hilmy, M.E., 1951. Beach sands of the Mediterranean coast of Egypt. Jour. Sed. Petrology, 21: 109-120.

James, N.P. and P.W. Choquette, 1984. Limestones: The meteoric diagenetic environment. Geosciences Canada, 11: 161-194.

Kinsman, D.J., 1969. Interpretation of $\mathrm{Sr}^{+2}$ concentrations in carbonate minerals and rocks. Jour. Sed. Petrology, 39: 484-508.

Land, L.S. and S. Epstein, 1970. Late Pleistocene diagenesis and dolomitization, North Jamaica. Sedimentology, 14: 187-200.

Land, L.S., S.W. Behrens and S.A. Fisherman, 1979. The ooids of Baffin bay, Texas, Jour. Sed. Petrology, 49: $1269-1278$

Lohmann, K.C., 1988. Geochemical patterns of meteoric diagenetic system and their application to studies of paleokarst. In: N.P. James and P.W. Choquette, (eds.), paleokarst, Springer-Verlag, New York, 420 pp.
Lorens, R.B., 1981. Sr, Cd, Mn, and Co distribution coefficients in calcite as a function of calcite precipitation rate. Geochim. Cosmochim. Acta, 45: 553-561.

MacKenzie, F.T. and J.D. Pigott, 1981. Tectonic controls of Phanerozoic sedimentary rock cycling. Jour. Geol. Soc. London, 138-196.

Medwedeff, D. and B. Wilkinson, 1983. Cortical fabrics in calcite and aragonite ooids. In. T. Preyt, (ed.), Coated Grains, Springer-Verlag, 109-115.

Morse, J.W. and M.L., Bender, 1990. Partition coefficients in calcite: examination of factors influencing the validity of experimental results and their application to natural systems. Chem. Geol., 82: 265-277.

Newell, D., E.G. Purdy, and J. Imbrie, 1960. Bahamian oolitic sand. Jour. Geol. 68: 481-497.

Pingitore, N.E. and M.P. Eastman, 1986. The coprecipitation of $\mathrm{Sr}$ with calcite at 25 degrees $\mathrm{C}$ and $1 \mathrm{~atm}$. Geochim. Cosmochim. Acta, 50: 2195-2203.

Popp, B.N. and B. Wilkinson, 1983. Holocene lacustrine ooids from Pyramid Lake, Nevada, In. T. Preyt, (ed.), Coated Grains, Springer-Verlag, 142-153.

Purdy, E.G., 1963. Recent calcium carbonate facies of the Great Bahama Bank. Jour. Geol. 71: 472-497.

Saller, A.H. and C.H. Moore, 1991. Geochemistry of meteoric calcite cements in some Pleistocene limestones. Sedimentology 38: 601-621.

Selim, A.A., 1974. Origin and lithification of the Pleistocene carbonates of the Salum area, western Coastal plain of Egypt. Jour.. Sed. Petrology, 44: 70-78.

Shukri, N.M., G. Philip, and R. Said, 1956. The geology of the Mediterranean coast between Rosetta and Bardia, part II: Pleistocene sediments Geomorphology and Microfacies. Inst. Egypt Bull., 37: 395-433.

Wagner, P.D., 1983. Geochemical characterization of meteoric diagenesis in limestone development and applications (Unpubl. Ph.D. Thesis) Providence, RI, Brown Univ., U.S.A., 386 pp.

Zeuner, F.E., 1952. Dating the Past, Methuen and Co., London, $516 \mathrm{pp}$. 